\title{
PENGGUNAAN MEDIA GAMBAR UNTUK MENINGKATKAN MOTIVASI BELAJAR MATA PELAJARAN SENI BUDAYA (TARI) MURID KELAS VII.4 SMPN 21 PEKANBARU
}

\author{
Rismiyenti \\ SMP Negeri 21 Pekanbaru \\ e-mail: rismiraihan@yahoo.com
}

\begin{abstract}
This devotional activity is downstream of research motivated by the low motivation of students learning art culture class VII.4 SMP Negeri 21 Pekanbaru. This study aims to improve the motivation to learn Cultural Art (Dance) with the use of image media on students of class VII.4 SMP Negeri 21 Pekanbaru. The subjects of this study are all students of class VII.4 SMPN 21 Pekanbaru which amounted to 41 people, the academic year 2016-2017. The form of research is classroom action research. The instrument of this research consisted of performance instrument and data collection instrument in the form of observation sheet of teacher activity and student activity. Based on the results of analysis and discussion as presented in chapter IV can be concluded that the use of image media can improve students' learning motivation of class VII.4 on the subject of Arts Culture (Dance) in SMPN 21 Pekanbaru. This success is caused by using the media images can stimulate student learning or help students, especially to concrete the various concepts that are abstract. Through the media, students are more motivated to learn, because students try to understand a lesson material in a more real (concrete). Based on the performance indicator can be concluded that the use of image media in improving students' learning motivation of class VII.4 on the subject of Arts Culture (Dance) in SMPN 21 Pekanbaru is said to succeed
\end{abstract}

Keywords: Learning Motivation, Picture Media

\begin{abstract}
Abstrak
Kegiatan pengabdian ini merupakan hilirisasi dari penelitian yang dilatarbelakangi oleh rendahnya motivasi belajar siswa pelajaran seni budaya kelas VII.4 SMP Negeri 21 Pekanbaru. Penelitian ini bertujuan untuk meningkatkan motivasi belajar Seni Budaya (Tari) dengan penggunaan media gambar pada siswa kelas VII.4 SMP Negeri 21 Pekanbaru. Subjek penelitian ini adalah semua siswa kelas VII.4 SMPN 21 Pekanbaru yang berjumlah 41 orang, tahun pelajaran 2016-2017. Bentuk penelitian adalah penelitian tindakan kelas. Instrumen penelitian ini terdiri dari instrumen unjuk kerja dan instrumen pengumpulan data berupa lembar observasi aktivitas guru dan aktivitas siswa. Berdasarkan hasil analisis dan pembahasan seperti disampaikan pada bab IV dapat disimpulkan bahwa penggunaan media gambar dapat meningkatkan motivasi belajar murid kelas VII.4 pada mata pelajaran Seni Budaya (Tari) di SMPN 21 Pekanbaru. Keberhasilan ini disebabkan dengan menggunakan media gambar dapat menstimulasi belajar murid atau membantu murid terutama untuk mengkongkretkan berbagai konsepnya yang sifatnya abstrak. Melalui media murid lebih termotivasi untuk belajar, karena murid berusaha memahami suatu materi pelajaran secara lebih nyata (kongkret). Berdasarkan indikator kinerja yang ditetapkan dapat disimpulkan bahwa penggunaan media gambar dalam meningkatkan motivasi belajar murid kelas VII.4 pada mata pelajaran Seni Budaya (Tari) di SMPN 21 Pekanbaru dikatakan berhasil
\end{abstract}

Kata kunci: Motivasi Belajar, Media Gambar

\section{PENDAHULUAN}

Proses pembelajaran adalah suatu proses yang dengan sengaja diciptakan untuk kepentingan murid, dari yang tidak tahu menjadi tahu. Agar murid senang dan bergairah belajar, guru berusaha menyediakan dan menggunakan semua potensi dan upaya.Belajar adalah suatu proses yang komplek 
terjadi pada diri setiap orang sepanjang hidupnya. Proses dapat terjadi karena adanya interaksi antara dengan lingkungannya.belajar dapat terjadi dimana saja dan kapan saja. Perubahan tingkah laku pada diri seseorang menunjukkan bahwa ia telah belajar.

Pelajaran Seni Budaya dianggap kurang menarik bahkan banyak murid yang menjadi pasif karena mereka hanya menerima materi pembelajaran dengan cara mendengarkan ceramah guru saja. Padahal yang seharusnya adalah proses pembelajaran berpusat pada murid dan menggunakan berbagai media pembelajaran dimana guru sebagai pembimbing.

Media (Azhar, 2007:1) merupakan bagian yang tidak terpisahkan dari proses pembelajaran demi tercapainya tujuan pendidikan. Media belajar dan media pembelajaran merupakan hal penting dalam proses pembelajaran. Membangkitkan motivasi dan rangsangan kegiatan belajar serta membawa pengaruh psikologis dan rangsangan kegiatan belajar bagi murid. Maka dapat dikatakan bahwa salah satu fungsi utama media pembelajaran adalah sebagai alat bantu mengajar yang ditaati dan diciptakan oleh guru.

Jika seorang guru tidak cermat memilih strategi mengajarnya akan berakibat tidak tercapainya hasil maksimal proses pembelajaran. Bahkan tujuan pembelajarannya akan terganggu atau gagal. Karena pendidikan merupakan usaha yang terencana untuk mewujudkan suasana belajar dan proses pembelajaran agar murid dapat mengembangkan potensi dirinya tersebut. Guru harus dapat membuat suatu tujuan dari proses pembelajaran dapat terwujud. Salah satunya dengan pemilihan yang tepat terhadap media dan media yang digunakan. Sehingga proses pembelajaran benar-benar dapat berjalan optimal.

Selama proses belajar mengajar banyak murid yang terlihat melamun dan tidak memperhatikan penyajian materi belajar, sering izin keluar kelas, atau ribut di dalam kelas hal ini menunjukan bahwa rendahnya motivasi belajar siswa. Tentu saja ini berpengaruh pada motivasi belajar murid dimana secara rata-rata motivasi belajar siswa pelajaran seni budaya hanya mencapai $45 \%$. Oleh karena itu, perlu diadakan perubahan dalam proses belajar mengajar. Salah satunya dengan pengadaan media gambar dalam proses pembelajaran.

Adakalanya sumber belajar murid hanya mengharapkan pertolongan guru, karena itu guru harus berinisiatif menggunakan alat bantu seperti alat peraga. Media gambar merupakan alat visual yang efektif karena dapat membantu guru memberi penjelasan yang lebih akurat kepada murid.

Berdasarkan keterangan di atas, maka penulis merasa tertarik untuk melakukan penelitian khususnya mengenai penggunaan media gambar dan diberi judul: "Penggunaan media gambar untuk meningkatkan motivasi belajar Mata Pelajaran Seni Budaya (Tari) murid kelas VII.4 SMPN 21 Pekanbaru"

\section{METODE}

Penelitian dilaksanakan di SMPN 21 Pekanbaru pada Kelas VII.4 pada tahun 2016. Penelitian ini telah dilaksanakan pada September 2016. Penelitian ini dilakukan dalam 2 siklus.

Subjek dalam penelitian ini adalah siswa VII.4 SMPN 21 Pekanbaru tahun pelajaran 20162017 dengan jumlah murid sebanyak 41 orang. Jenis penelitian ini adalah Penelitian Tindakan Kelas (PTK). Penelitian Tindakan Kelas (PTK) merupakan salah satu langkah dalam mengembangkan keterampilan dan meningkatkan kinerja guru agar keberhasilan proses belajar mengajar dalam pencapaian hasil belajar dapat di peroleh semaksimal mungkin

\section{HASIL DAN PEMBAHASAN}

\subsection{Hasil}

\subsubsection{Sebelum Tindakan}

Pada observasi pendahuluan, penulis telah melakukan obesrvasi tentang prestasi belajar murid dalam mata peajaran seni budaya (tari) 41 orang.

Untuk mengetahui gambaran dari motivasi belajar penulis kemukakan nilai motivasi sebelum tindakan kelas dilakukan dapat dilihat pada tabel berikut ini 
Tabel 1. Motivasi Sebelum Tindakan

\begin{tabular}{|c|c|c|c|c|c|c|c|c|c|c|c|}
\hline \multirow[t]{2}{*}{ No } & \multirow[t]{2}{*}{ Nama Siswa } & \multicolumn{8}{|c|}{ Aktivitas Siswa } & \multirow{2}{*}{$\begin{array}{c}\text { Jumlah } \\
\text { Skor }\end{array}$} & \multirow{2}{*}{ Kategori } \\
\hline & & 1 & 2 & 3 & 4 & 5 & 6 & 7 & 8 & & \\
\hline 1 & Abi Siddiq & 1 & 2 & 3 & 1 & 3 & 2 & 3 & 2 & 17 & Rendah \\
\hline 2 & Adinda Dwi & 1 & 3 & 1 & 3 & 1 & 2 & 3 & 2 & 16 & Rendah \\
\hline 3 & Adinda Rosa & 1 & 1 & 3 & 2 & 1 & 2 & 3 & 2 & 15 & Sangat Rendah \\
\hline 4 & Alya Madani & 3 & 1 & 1 & 2 & 1 & 1 & 2 & 1 & 12 & Sangat Rendah \\
\hline 5 & Arief Akbar & 1 & 1 & 2 & 1 & 2 & 3 & 1 & 3 & 14 & Sangat Rendah \\
\hline$\frac{5}{6}$ & Bella Puspita & 3 & 1 & 1 & 1 & 2 & 1 & 1 & 4 & 14 & Sangat Rendah \\
\hline 7 & Farhan Rafi & 3 & 1 & 4 & 1 & 3 & 2 & 3 & 1 & 18 & Rendah \\
\hline 8 & Fito Sanjaya & 3 & 4 & 3 & 2 & 1 & 2 & 3 & 2 & 20 & Rendah \\
\hline 9 & Glori Imam & 1 & 1 & 3 & 1 & 1 & 2 & 1 & 3 & 13 & Sangat Rendah \\
\hline 10 & Habil Arifin & 1 & 3 & 1 & 3 & 1 & 3 & 1 & 1 & 14 & Sangat Rendah \\
\hline 11 & Hidayat Hatta & 2 & 3 & 1 & 1 & 3 & 1 & 2 & 1 & 14 & Sangat Rendah \\
\hline 12 & Humaida & $\begin{array}{llll}1 & & & \\
\end{array}$ & 1 & 1 & 3 & 2 & 2 & 1 & 4 & 15 & Sangat Rendah \\
\hline 13 & Irfan Santono & 1 & 3 & 2 & 2 & 2 & 2 & 2 & 2 & 16 & Rendah \\
\hline 14 & Irgo Yuri & 1 & 3 & 2 & 1 & 2 & 3 & 1 & 3 & 16 & Rendah \\
\hline 15 & Irviana Tri & 1 & 3 & 2 & 1 & 2 & 3 & 1 & 3 & 16 & Rendah \\
\hline 16 & Lestari Sanjaya & 3 & 1 & 4 & 1 & 3 & 2 & 3 & 1 & 18 & Rendah \\
\hline 17 & M Febian & 3 & 4 & 3 & 2 & 1 & 2 & 3 & 2 & 20 & Rendah \\
\hline 18 & Maria Veronioca & 1 & 1 & 3 & 1 & 1 & 2 & 1 & 3 & 13 & Sangat Rendah \\
\hline 19 & Maulana Siddiq & 1 & 3 & 1 & 3 & 1 & 3 & 1 & 1 & 14 & Sangat Rendah \\
\hline 20 & Mayang & 2 & 3 & 1 & 1 & 3 & 1 & 2 & 1 & 14 & Sangat Rendah \\
\hline 21 & Mariati & $\begin{array}{llll}1 & & & \\
\end{array}$ & 1 & 1 & 3 & 2 & 2 & 1 & 4 & 15 & Sangat Rendah \\
\hline 22 & Mftakh & 1 & 3 & 2 & 2 & 2 & 2 & 2 & 2 & 16 & Rendah \\
\hline 23 & Muhammad Rafli & 1 & 3 & 2 & 2 & 2 & 2 & 2 & 2 & 16 & Rendah \\
\hline 24 & Muhammad Ridho & 2 & 3 & 1 & 1 & 3 & 1 & 2 & 1 & 14 & Sangat Rendah \\
\hline 25 & Muhammad Syauqi & 1 & 1 & 1 & 3 & 2 & 2 & 1 & 4 & 15 & Sangat Rendah \\
\hline 26 & Nessa Muthia & 1 & 3 & 2 & 2 & 2 & 2 & 2 & 2 & 16 & Rendah \\
\hline 27 & Nuraini & 1 & 3 & 2 & 1 & 2 & 3 & 1 & 3 & 16 & Rendah \\
\hline 28 & Ocha Pricilia & 3 & 1 & 4 & 1 & 3 & 2 & 3 & 1 & 18 & Rendah \\
\hline 29 & Rahmalia & 3 & 4 & 3 & 2 & 1 & 2 & 3 & 2 & 20 & Rendah \\
\hline 30 & Retno Atriana & 1 & 1 & 3 & 1 & 1 & 2 & 1 & 3 & 13 & Sangat Rendah \\
\hline 31 & Rizki Febian & 1 & 3 & 1 & 3 & 1 & 3 & 1 & 1 & 14 & Sangat Rendah \\
\hline 32 & Rizky Maimunar & 2 & 3 & 1 & 1 & 3 & 1 & 2 & 1 & 14 & Sangat Rendah \\
\hline 33 & Rizky Wahyuda & 1 & 1 & 1 & 3 & 2 & 2 & 1 & 4 & 15 & Sangat Rendah \\
\hline 34 & Ryan Hidayat & 1 & 3 & 2 & 2 & 2 & 2 & 2 & 2 & 16 & Rendah \\
\hline 35 & Silfia & 1 & 3 & 2 & 1 & 2 & 3 & 1 & 3 & 16 & Rendah \\
\hline 36 & Sisca & 1 & 1 & 2 & 1 & 2 & 3 & 2 & 3 & 15 & Sangat Rendah \\
\hline 37 & Suci Rahmadani & 2 & 2 & 3 & 1 & 3 & 2 & 3 & 1 & 17 & Rendah \\
\hline 38 & Syerlyu Yolanda & 1 & 2 & 2 & 1 & 2 & 3 & 3 & 1 & 15 & Sangat Rendah \\
\hline 39 & Tarmi & 1 & 1 & 2 & 1 & 2 & 3 & 2 & 3 & 15 & Sangat Rendah \\
\hline 40 & Wirangga & 1 & 2 & 3 & 1 & 2 & 1 & 2 & 3 & 15 & Sangat Rendah \\
\hline 41 & Zacky Fuadi & 3 & 1 & 2 & 2 & 2 & 3 & 1 & 3 & 17 & Rendah \\
\hline & Jumlah & 64 & 88 & 84 & 68 & 79 & 87 & 76 & 91 & 637 & Tinggi \\
\hline & Rata-Rata & 2 & 2 & 2 & 2 & 2 & 2 & 2 & 2 & 16 & Sangat Rendah \\
\hline
\end{tabular}

Berdasarkan data di atas dapat disimpulkan bahwa motivasi belajar siswa dalam proses pembelajaran sebelum menerapkan pembelajaran denga media gambar pada data awal secara klasikal diperoleh jumlah skor 637, angka ini berada pada kategori sangat rendah

\subsubsection{Siklus I}

Motivasi belajar siswa pada siklus 1 pertemuan pertama dalam mata pelajaran seni budaya (tari) siswa secara klasikal tergolong rendah dengan perolehan jumlah skor 786

Motivasi belajar siswa secara klasikal masih tergolong rendah, namun meningkat dari siklus 1 pertemuan kedua dengan perolehan jumlah skor 948, angka ini berada pada pada kategori rendah

Memperhatikan deskripsi Seni Budaya (Tari) proses pembelajaran yang dikemukakan di atas dan melihat motivasi belajar murid pada pelajaran seni budaya (tari) tersebut, maka berdasarkan hasil pembahasan peneliti dan pengamat terhadap perbaikan pembelajaran pada siklus pertama terdapat beberapa kekuatan dan kelemahan pembelajaran diantaranya:

1. Pengelolaan pembelajaran oleh peneliti telah sesuai dengan tahapan yang dimuat dalam RPP. Namun penggunaan media gambar dalam proses pembelajaran guru masih mengalami beberapa 
kelemahan khususnya dalam penyajian materi yang kurang sistematis, kurang serius dalam membimbing, kurang semarak dalam pemberian penghargaan.

2. Motivasi dan keantusiasan murid mengikuti pembelajaran cukup baik.

3. Secara umum aktivitas murid dalam belajar sudah mulai terfokus pada tugas-tugas belajarnya namun masih perlu pengawasan yang lebih ketat dan mendidik.

4. Motivasi belajar murid setelah perbaikan pembelajaran lebih baik, jika dibandingkan dengan motivasi belajar murid sebelum tindakan.

5. Kemandirian murid dalam membangun pengetahuannya belum optimal, karena murid masih belum terbiasa dengan penggunaan media gambar yang diterapkan.

Tindakan yang dilakukan guru pada tahap awal masih membingungkan murid. Sebagian murid meminta guru untuk cepat memberikan jawaban dari permasalahan yang diajukan, hanya sebagian kecil murid yang berusaha untuk tetap menemukan pemecahan dari permasalahan yang diajukan. Peran guru dalam membimbing murid masih sangat dibutuhkan untuk memecahkan masalah yang diajukan, ini dapat dilihat dari ketergantungan murid terhadap bimbingan guru masih sangat dominan. Murid sulit untuk memecahkan permasalahan yang diberikan guru oleh karena tidak memiliki sumber informasi selain guru. Kebanyakan murid belum mempunyai kepercayaan diri bahwa mereka memiliki kemampuan untuk dapat memecahkan masalah sendiri. Dari aspek afektif murid memiliki sikap yang cukup positif dan minat yang masih sedikit kurang antusias untuk turut melibatkan diri dalam memecahkan permasalahan yang ada pada saat tanya jawab. Namun demikian guru harus lebih memberikan perhatian khusus terutama pada murid yang menunjukkan sikap, minat, dan motivasi belajar yang masih rendah.

Berdasarkan hal di atas perlu diadakan siklus berikutnya. Kekurangan yang perlu diatasi dari siklus pertama adalah: 1) Kapada murid yang sikapnya dan minatnya cukup serta nilai motivasi belajar kognitif rendah perlu diberikan perhatian khusus dengan membimbing mereka secara individual. 2) Oleh karena waktu yang dibutuhkan murid untuk memecahkan permasalahan atau memahami nilai yang terkandung dalam media gambar cendruing lama, maka guru perlu memberikan batasan waktu kepada murid untuk memecahkan masalah. 3) Kecuali kepada murid yang masih bernilai rendah, bimbingan guru terhadap murid lainnya perlu dikurangi untuk menumbuhkan kepercayaan diri bahwa mereka mampu memecahkan masalah sendiri. Hal ini juga berguna untuk memastikan bahwa motivasi belajar meningkat, bukan karena bimbingan guru

\subsubsection{Siklus II}

Motivasi belajar siswa pada siklus II pertemuan pertama dalam mata pelajaran seni budaya (tari) siswa secara klasikal tergolong tinggi dengan perolehan jumlah skor 1262 , angka ini berada pada pada kategori tinggi

Motivasi belajar siswa pada siklus II pertemuan pertama dalam mata pelajaran Seni Budaya siswa secara klasikal tergolong sangat tinggi dengan perolehan jumlah skor 1409

Jika diperhatikan hasil siklus kedua, motivasi belajar yang ditunjukkan oleh murid mengalami peningkatan dibanding dengan siklus pertama. Artinya tindakan yang diberikan guru pada siklus kedua berdampak lebih baik dari tindakan pada siklus pertama. Hal ini memberikan gambaran bahwa untuk bisa memecahkan masalah, murid membutuhkan waktu secara perlahan-lahan. Pada awalnya murid perlu dibimbing secara intensif, namun secara berangsur-angsur murid diberi kesempatan untuk bisa memecahkan permasalahan tanpa bantuan guru.

Pembatasan waktu yang diberikan untuk memecahkan masalah yang diajukan guru kepada murid berdampak pula kepada hasil yang baik. Murid tidak membuang-buang waktu hingga dua pertemuan untuk menyelesaikan satu permasalahan. Bimbingan khusus yang ditujukan kepada sebagain kecil murid juga menunjukkan hasil yang baik. Ini dapat ditinjau dari berkurangnya jumlah murid yang bernilai di bawah rata-rata (65) lebih kecil jika dibandingkan dengan siklus pertama.

Permasalahan yang ditemukan dalam siklus kedua yang nampak dilihat adalah mengenai soal kasus yang diajukan kurang menantang dan merangsang murid untuk berfikir lebih keras lagi sehingga kompetensi yang mereka miliki dapat betul-betul diterapkan dalam kehidupan sehari-sehari dan murid dapat merasakan manfaat dari apa yang telah mereka pelajari, dengan melakukan sendiri/mempraktekkan sendiri apa yang dipelajari maka diharapkan murid mendapat pengalaman 
bermakna sehingga mereka menjadi lebih paham dengan materi yang diberikan. Dalam hal ini perlu wawasan guru yang lebih luas untuk mencari permasalahan yang kontekstual. Jadi guru harus dapat memilih materi-materi apa saja yang dapat disajikan

\subsection{Pembahasan}

Data dari Dari hasil penelitian pada siklus I menunjukkan bahwa motivasi belajar belum mencapai indikator yang ditetapkan (belum tercapainya ketuntasan individu sebanyak 15). Hal ini disebabkan pengelolaan pembelajaran pada siklus I yang belum optimal seperti dijelaskan dalam siklus I, seperti; Khususnya pada aspek (3) mengamati guru dalam menyiapkan bahan yang akan digunakan (5) mengomentari gambar dan murid lain memberikan tanggapan terhadap komentar tersebut hanya 8 hingga 9 orang murid yang tergolong aktif. Hal ini mengindikasikan bahwa proses pembelajaran yang dibawakan peneliti masih perlu perencanaan yang lebih baik dengan memperhatikan kelemahan kekuatan yang telah teridentifikasi pada siklus I sebagai dasar perbaikan pada siklus II.

Berdasarkan data di atas diketahui bahwa terjadinya peningkatan motivasi belajar dari siklus I ke siklus II. Sebagaiaman siklus I mencapai skor 948 berada pada kategori rendah sedangkan apda siklus II mencapai skor 1409 dengan kategori sangat tinggi. Keadaan ini menunjukkan bahwa perbaikan pembelajaran pada mata pelajaran seni budaya (tari) dengan menggunakan media gambar dapat dikatakan berhasil, meskipun ketuntasan individu belum tercapai sepenuhnya.

Dari data di atas juga diketahui bahwa ada hubungan erat antara peningkatan aktivitas guru dan murid dengan motivasi belajar murid. Keadaan ini membuktikan bahwa keaktivan guru dan murid mempengaruhi keberhasilan belajar murid. Hal ini didukung oleh adanya kecenderungan meningkatnya aktivitas guru dan murid diiringi dengan meningkatnya prestasi belajar murid.

Kelemahan-kelemahan penggunaan media gambar pada siklus I tersebut setelah diperbaiki pada siklus II dan mencapai tingkat sempurna ternyata dapat meningkatkan motivasi belajar murid. Melalui perbaikan penggunaan media gambar pada siklus II tersebut.

Meningkatnya motivasi belajar pada siklus dua dibandingkan pada siklus I menunjukkan bahwa perbaikan pembelajaran yang dibawakan dapat memecahkan permasalahan yang dihadapi. Artinya, perencanaan pembelajaran yang dibuat sesuai untuk mengatasi permasalahan rendahnya motivasi belajar murid yang terjadi di dalam kelas selama ini. Selanjutnya, adanya peningkatan motivasi belajar murid pada mata pelajaran seni budaya (tari) dari sebelumnya ke siklus I dan kesiklus II menunjukkan bahwa penggunaan media gambar dapat meningkatkan motivasi belajar seni budaya (tari) murid kelas VII.4 SMPN 21 Pekanbaru Kabupaten Kampar.

Keadaan di atas senada dengan pendapat yang dikemukakan oleh Jerone Bruner dalam Elida Prayitno mengemukakan bahwa kalau dalam belajar murid diberi pengalaman langsung (melalui media, demonstrasi, Field trip, dramatisasi), maka situasi pengajarannya itu akan meningkatkan kegairahan dan motivasi tersebut dalam belajar. Kemudian Leming dan Levie dalam Elida Prayitno, menyimpulkan dari berbagai penelitian Bruner bahwa media pengajaran memberikan pengalaman kongkret yang memudahkan murid belajar, yaitu mencapai penguasaan, mengingat dan memahami simbol-simbol yang abstrak.

Berdasarkan kedua penjelasan tersebut di atas dan dari berbagai penelitian yang telah mereka lakukan itu, maka tidak perlu kita ragukan lagi tentang pentingnya media pengajaran dalam meningkatkan motivasi belajar murid

Dari hasil penelitian dan pembahasan seperti telah duiraikan di atas menjelaskan bahwa dengan penggunaan media gambar yang tepat pada murid kelas VII.4 SMPN 21 Pekanbaru maka aktivitas murid menjadi lebih aktif dan pada gilirannya motivasi belajar murid menjadi lebih baik. Informasi ini membuktikan bahwa hipotesis peneliti yang berbunyi "Penggunaan media gambar dalam pembelajaran dapat meningkatkan motivasi belajar murid dalam pelajaran seni budaya (tari) . Karena murid akan menjadi lebih tertarik dengan penjelasan materi pembelajaran dengan menggunakan gambar-gambar dari pada hanya dengan ceramah saja "dapat diterima" 


\section{KESIMPULAN}

Berdasarkan hasil analisis dan pembahasan seperti disampaikan pada bab IV dapat disimpulkan bahwa penggunaan media gambar dapat meningkatkan motivasi belajar murid kelas VII.4 pada mata pelajaran Seni Budaya (Tari) di SMPN 21 Pekanbaru. Keberhasilan ini disebabkan dengan menggunakan media gambar dapat menstimulasi belajar murid atau membantu murid terutama untuk mengkongkretkan berbagai konsepnya yang sifatnya abstrak. Melalui media murid lebih termotivasi untuk belajar, karena murid berusaha memahami suatu materi pelajaran secara lebih nyata (kongkret). Berdasarkan indikator kinerja yang ditetapkan dapat disimpulkan bahwa penggunaan media gambar dalam meningkatkan motivasi belajar murid kelas VII.4 pada mata pelajaran Seni Budaya (Tari) di SMPN 21 Pekanbaru dikatakan berhasil.

\section{SARAN}

Bertolak dari kesimpulan dan pembahasan hasil penelitian di atas, berkaitan dengan menggunakan media diskusi yang telah dilaksanakan, peneliti mengajukan beberapa saran, yaitu:

a. Agar pelaksanaan penggunaan media gambar tersebut dapat memberikan hasil yang optimal, maka sebaiknya guru lebih sering menerapkannya.

b. Penggunaan media gambar akan lebih efektif bila gambar yang disajikan benar-benar mengandung nilai-nilai yang terkandung dalam materi pelajaran.

c. Perlunya penggunaan media belajar yang bervariatif demi pencapaian motivasi belajar yang optimal

\section{DAFTAR PUSTAKA}

[1] Arshad Azhar, Media Pembelajaran, Rajawali Pers, Jakarta, 2007.

[2] Elida Prayitno, Motivasi Dalam Belajar. Jakarta, Depdikbud. 1989.

[3] Hamalik, Oemar, Media Pendidikan, Jakarta, Bumi Aksara, 1997.

[4] Ibrahim \& Nana Syaodih. 2004. Perencanaan Pengajaran Jakarta: Rineka Cipta

[5] Martin Handoko. 2002. Motivasi Daya Penggerak Tingkah Laku. Yogyakarta: Kanisius

[6] Sadiman, Arief, dkk, Media Pendidikan, Jakarta, PT. Raja Grafindo Persada, 2007.

[7] Zainal Aqib \& Elham Rohmanto, Membangun Profesionalisme Guru dan Pengawas Sekolah, Bandung, CV. Yrama Widya, 2007. 